\title{
Jihad dalam Konteks Hadis' Aḥkām dan Kontekstualisasi Maknanya di Era Milenial
}

\author{
Muhammad Gazali Rahman, Aisma Maulasa
}

IAIN Sultan Amai Gorontalo

Email: gazali.iain@gmail.com; aismamaulasa628@gmail.com

\begin{abstract}
Prophet Muhammad left two very valuable legacies, namely the Qur'an and Hadith. These two legacies have always been the main source of reference for anyone in solving the myriad of life's problems. The complexity of human life in the end also demands the reading and review of applicable sources that have been appreciated by the Prophet Muhammad on his period to be contextualized and exist all the time. Likewise, the emergence of modern challenges that tend to reduce the authority of prophethood is a challenge for Muslims to reconstruct the religious foundations that have long been the formal law in interacting. This research is library research which is analyzed with a normative approach and a contextual approach. The results of this study indicate that as part of Islamic teachings, jihad in the early Islamic narrative may be different from the current version of jihad, either due to contextualization of meaning or due to a reduction in the true essence of jihad.
\end{abstract}

Keywords: Jihad, Contextualization, Hadith Law

\section{Jihad in the Context of Hadith Law and Contextual Meaning in the Millennial Era}

\begin{abstract}
Abstrak: Nabi Muhammad saw. meninggalkan dua warisan yang sangat berharga yaitu Alquran dan hadis. Kedua warisan inilah yang senantiasa menjadi sumber rujukan utama bagi siapa saja dalam menyelesaikan segudang problematika kehidupan. Kompleksitas kehidupan manusia pada akhirnya juga menuntut pembacaan dan pengkajian ulang terhadap sumber-sumber aplikatif yang telah diapresiasikan oleh Nabi Muhammad saw. di zamannya untuk dapat dikontekstualisasikan dan tetap eksis sepanjang zaman. Begitu pula munculnya tantangan modern yang cenderung mereduksi otoritas kenabian merupakan tantangan tersendiri bagi umat Islam untuk merekonstruksi kembali fondasi-fondasi agama yang sekian lama telah menjadi hukum formal dalam berinteraksi. Penelitian ini adalah penelitian kepustakaan yang dianalisis dengan pendekatan normatif dan kontektual. Hasil penelitian ini menunjukkan sebagai bagian dari ajaran Islam, jihad dalam narasi Islam awal bisa jadi berbeda dengan jihad versi sekarang, baik disebabkan oleh kontekstualisasi makna maupun oleh karena reduksi terhadap esensi jihad yang sesungguhnya.
\end{abstract}

Kata Kunci: Jihad, Kontekstualisasi, Hadiś Ahkām 


\section{A. Pendahuluan}

Di kalangan umat Islam tidak ada kata-kata yang lebih menggetarkan seperti halnya kata-kata "jihad". Resonansinya bahkan mungkin terasa lebih kuat lagi justru di kalangan umat agama lain. Begitu kata-kata jihad diserukan, lazimnya diiringi pekik "Allahu Akbar", maka seakan genderang perlawanan telah ditabuh dan pedang telah dihunuskan. Berbagai aksi kekerasan mulai dari serangkaian bom bunuh diri di Palestina, perang gerilya di Afganistan, pembajakan pesawat untuk meledakkan gedung Word Trade Centre dan Pentagon di Amerika, perang antar golongan di Ambon dan Poso, peristiwa bom Bali, serta aksi-aksi kekerasan lain di berbagai tempat, semuanya diatasnamakan oleh para pelakunya atas nama jihad.

Istilah jihad dewasa ini, hampir-hampir telah menimbulkan persepsi yang mengandung unsur pejoratif. Ini disebabkan, karena istilah tersebut dipakai dalam kaitannya dengan berbagai peristiwa kerusuhan sosial pada 1970-an di Indonesia yang disebut sebagai gerakan "Komando Jihad". Tidak diketahui secara persis, apakah nama itu dipakai oleh kelompok yang bersangkutan, ataukah hanya penamaan dari luar yang merupakan bagian dari rekayasa politik militer. Apabila hal yang pertama yang benar, maka pemakaian itu berarti mereduksi, bahkan mendegradasi pengertian jihad. Sedangkan hal kedua telah menimbulkan ketakutan masyarakat luas untuk memakai istilah itu. ${ }^{5}$

Menarik untuk disimak, adalah kenyataan bahwa Islam sesungguhnya merupakan agama damai. Agama pembawa, pengibar, dan penentu, serta pencipta perdamaian bagi seluruh umat manusia. Umat Islam diwajibkan selalu mengutamakan jalan damai, baik di dalam Islam itu sendiri, maupun ke luar Islam. Jika umat Islam sudah harus dengan terpaksa melaksanakan peperangan dengan non Muslim, umat Islam dituntut untuk taat, patuh, dan tunduk pada petunjuk, pedoman, etika, dan kode etik peperangan, yang mengacu pada isi Alquran dan hadis.

${ }^{5}$ M. Dawam Rahardjo, Ensiklopedi Al-Qur'an; Tafsir Sosial Berdasarkan Konsep-konsep Kunci (Cet. I; Jakarta: Paramadina, 1996), 507. 
Tidak dapat dipungkiri bahwa para pelaku peledakan "bom-bom" tersebut adalah umat Muslim, yang serta merta pada mereka itu telah dicap sebagai teroris. Persoalannya adalah, bagaimana terminologi jihad dalam Islam, dan apakah pelaku teroris tersebut dianggap sebagai berjihad di jalan Allah swt. Persoalan inilah yang mesti dipahami secara bijak dengan cara mengkaji ulang hadis-hadis Nabi saw. secara tematik yang terkait dengan jihad. Lebih menarik lagi, bila hadis-hadis tentang jihad dan terorisme tersebut tersebut dikaji berdasarkan pemikiran kekinian dan keindonesiaan. Sehingga, akan diketahui makna jihad menurut hadis yang kemudian dapat dijadikan pegangan bahwa Islam adalah agama yang benar-benar toleran (tasāmuh), dan cinta perdamaian.

Pencarian tematik dilakukan berdasarkan lafaz-lafaz yang identik atau sinonim dengan lafaz jihăd. Beberapa kata kunci yang menjadi pijakan dalam penelusuran beberapa riwayat berdasarkan metode tersebut antara lain: jihād/mujāhid, qitāl, hạa, syuhadā', dan fì sabìilillāh. ${ }^{6}$ Penulusuran berdasarkan beberapa kata kunci tersebut menemukan sebanyak 461 hadis berdasarkan lafaz jihād, 229 hadis berdasarkan lafaz qitāl, 1946 hadis berdasarkan lafaz harb, 167 hadis berdasarkan lafaz syuhadā', dan 904 hadis berdasarkan lafaz fí sabīlillāh. Dari sekian banyak hadis tersebut, ditemukan hadis-hadis yang mengalami periwayatan maknawi (bi al-ma'na) dan didukung oleh hadis-hadis semakna lainnya. Tentunya dengan kata-kata kunci tersebut tidak menutup kemungkinan hadis yang ditemukan berulang atau terdapat pada kitab hadis yang sama. Misalnya, terdapat hadis dengan lafaz jihād yang bergandengan dengan fî̀ sabỉlillāh, tetapi ada pula hadis yang menggunakan lafaz fỉ sabỉilläh yang tidak bergandengan dengan lafaz jihāà.

Begitupula terhadap hadis-hadis tentang keutamaan jihad, jika mengacu kepada kitāb atau $b \bar{a} b$ "Keutamaan Jihad", maka akan ditemukan perbedaan penempatan hadis oleh setiap mukharrij. Bukhāri misalnya, pada bāa Keutamaan Jihad, ia memuat hadis tentang jihad yang redaksinya bergandengan dengan keutamaan salat dan berbuat baik pada orang tua. Sedangkan oleh Muslim, pada

\footnotetext{
${ }^{6}$ Penelusuran berdasarkan lafaz yang menjadi kata kunci tersebut dapat dirujuk pada Arnold John Wensinck, Concordance et Indices de la Musulmane, terj. Muhammad Fuad Abd al-Baqy, alMu’jam al-Mufahras li Alfä al-Hadiś al-Nabawi, Juz I (Leiden: EJ. Brill, 1936), 387-389.
} 
bab yang sama, ia memuat hadis dengan redaksi yang terkait dengan ganjaran, pahala, atau jaminan Allah kepada mereka yang berjihad. Adapun hadis jihad yang redaksinya bergandengan dengan keutamaan salat dan berbuat baik pada orang tua ditempatkan pada Kitāb Imān. Oleh mukharrij lainnya, hadis keutamaan jihad versi Bukhāri ditempatkan pada kitāb Salāt, Mawāqìt (Waktu-waktu salat), dan Musnad al-Mukašsiriñ min al-Ṣậăbah (Sahabat yang banyak meriwayatkan hadis).

Jihad adalah perang suci untuk menyebarluaskan Islam ke wilayah-wilayah non Muslim atau mempertahankan Islam dari ancaman. ${ }^{7}$ Menurut Fazlurrahman, jihad adalah perjuangan bersifat total dengan harta benda, dan jiwa, atau menyerahkan diri dan harta benda ke jalan Allah yang bertujuan untuk menegakkan perintah-perintah Allah. ${ }^{8}$

Pengertian jihad dalam Mu'jam al-Maqayis al-Lughah pada asalnya mengandung arti kesulitan atau kesukaran, dan yang sepadan dengannya. ${ }^{9}$ Kata jihad juga terambil dari kata jahd yang berarti letih atau sukar dan kata juhd yang berarti kemampuan. ${ }^{10}$ Term jihad tersusun dari akar kata ج, ج, yang memiliki arti dasar al-masyaqqat wa mā yuqarribuh, "kesulitan yang memiliki kedekatan makna dengannya". Bentuk dari akar kata tersebut adalah al-jahdu, al-majhūd, al-juhdu, bermakna al-taqah, "kemampuan". Sementara kata al-majhūd memiliki makna allaban al-lażi ukhrija zubdahu, "susu yang dikeluarkan inti sarinya". Susu tersebut sangat sulit dikeluarkan kecuali dengan upaya yang sulit dan kesungguhan. Sementara makna yang memiliki kedekatan dengan kata kesulitan adalah: "keras, sungguh-sungguh". 11

Penjelasan makna akar kata ini memberikan informasi bahwa jihad itu memiliki makna upaya yang sungguh-sungguh, upaya yang sulit, usaha maksimal, keras, dan kuat. Oleh karena itu, makna jihad adalah upaya keras yang sangat sulit

\footnotetext{
${ }^{7}$ Nicholas Drake and Elizabeth Davis (Eds.), The Concise Encyclopedia of Islam (Singapore: Tien Wah Press, 1989), 209.

${ }^{8}$ Fazlurrahman, Islam (New York: Achor Book, 1968), 34. Lihat pula Fazlurrahman, Major Themes of The Qur'an (Chicago: Bibliotheca Islamica, 1980), 36.

${ }^{9}$ Abū Husain Aḥmad bin Fāris bin Zakarīya, Mu’jam Maqāyis al-Lugah, Juz I (Beirut: Dār al-Fikr, 1979), 486.

${ }^{10}$ Al-Ragib al-Asfahāniy, Mu'jam Mufradāt Alfāz al-Qur'ān (Beirut: Dār al-Fikr, t.th.), 99.

${ }^{11} \mathrm{Abu}$ Husain Ahmad, Mu’jam Maqāyis, 487.
} 
dan membutuhkan kesungguhan dan kekuatan serta kemampuan secara maksimal. Demikian pula dalam analisis leksikal, kata jihad bermakna kemampuan dan kesulitan, senada dengan perkataan Ibnu Manzur, dalam kamus Lisān al-’Arab, jihad adalah:

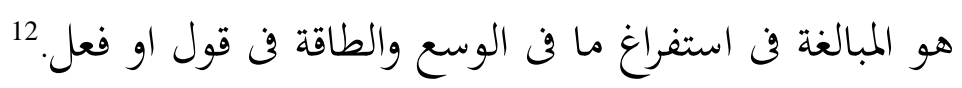

Maknanya:

Jihad adalah berusaha dan menghabiskan segala daya dan kekuatan, baik berupa ucapan maupun perbuatan).

Berpijak dari analisa semantik tersebut, maka pemahaman yang utuh tentang jihad adalah kesukaran, kesulitan, kemampuan, kekuasaan, pengorbanan, ujian, dan puncak dari masalah. Jihad dikatakan kesukaran karena di dalamnya banyak rintangan-rintangan dan musuh-musuh yang benar-benar sukar diatasi tanpa kemampuan, baik kemampuan fisik seperti kemampuan badan yang sehat, kemampuan material maupun kemampuan non material, seperti kemampuan keilmuan atau kepandaian.

\section{B. Konsep Jihad dalam Berbagai Perspektif Tokoh}

Konsep jihad dalam berbagai pandangan atau ijtihad memiliki berbagai pengertian. Terkadang konsep jihad disalahgunakan dalam konsep melakukan tindakan anarkis dan meneror. Olehnya itu fatwa Majelis Ulama Indonesia (MUI) Nomor 3 Tahun 2004 tentang Terorisme, mendefinisikan terorisme adalah tindakan kejahatan terhadap kemanusiaan dan peradaban yang menimbulkan ancaman serius terhadap kedaulatan negara, bahaya terhadap keamanan, perdamaian dunia serta merugikan kesejahteraan masyarakat. Terorisme adalah salah satu bentuk kejahatan yang diorganisasi dengan baik, bersifat trans-nasional dan digolongkan sebagai kejahatan luar biasa (extra-ordinary crime) yang tak membeda-bedakan sasaran.

\footnotetext{
${ }^{12}$ Ibnu Manzūr, Lisān al-'Arb, Juz XV (Kairo: Dār al-Mișriyah li al-Ta' lif wa al-Tarjamah, t.th.), 109; Ahsin A. W. al-Hafiz, Kamus Ilmu Al-Quran (Cet. I; Jakarta: Hamzah, 2005), 138; Munawwir, A.W. Kamus al Munawwir Arab-Indonesia (Cet. XXV; Surabaya: Pustaka Progresif, 2002), 217.
} 
MUI menjelaskan perbedaan jihad dengan terorisme. Adapun terorisme sifatnya merusak (ifsād) dan anarkis. Tujuannya untuk menciptakan rasa takut dan menghancurkan pihak lain, serta dilakukan tanpa aturan dan sasaran tanpa batas. Sedangkan jihad, sifatnya melakukan perbaikan (iṣlạh) sekalipun dengan cara peperangan. Tujuannya menegakkan agama Allah dan membela pihak-pihak yang terzalimi. Jihad dilakukan dengan mengikuti aturan yang ditentukan oleh syariat dengan sasaran musuh yang sudah jelas. Dengan demikian, hukum melakukan teror adalah haram, baik dilakukan oleh perorangan, kelompok, maupun negara. Sedangkan melakukan jihad hukumnya wajib.

Batrus al-Bustāniy dalam karyanya yang berjudul Dā'irat al-Ma'arif mengatakan bahwa jihad adalah:

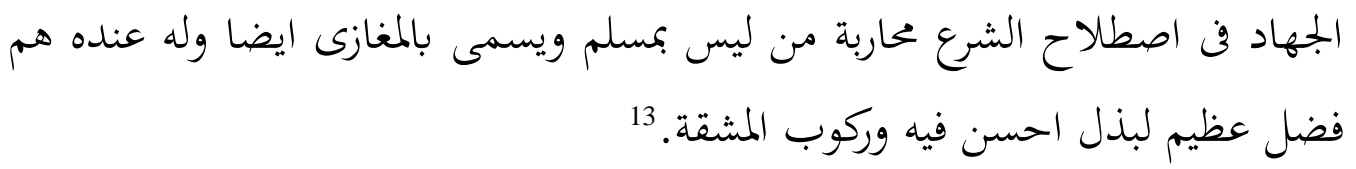

Maknanya:

Jihad dalam istilah hukum Islam adalah memerangi orang non Muslim dan dinamakan perang yang di dalamnya penuh dengan muatan keutamaan dan keagungan dengan mengerahkan yang terbaik untuk kepentingan perang penuh kesulitan dan bahaya).

Ali ‘Abd al-Raziq memandang jihad sebagai berikut:

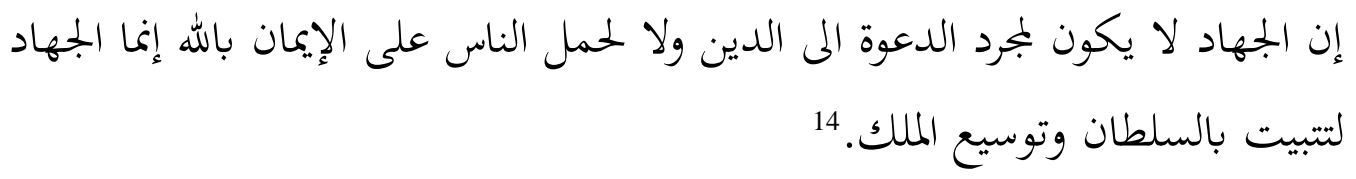

Maknanya:

Jihad dipahami tidak hanya sebagai upaya menegakkan dakwah Islam, atau menyeru manusia untuk mengokohkan iman, akan tetapi jihad adalah usaha mengokohkan pemerintah dan memperluas kekuasaan.

H. M. Quraish Shihab membedakan istilah mujāhid dengan istilah jihād. Mujahid adalah orang yang mencurahkan seluruh kemampuannya dan berkorban

\footnotetext{
${ }^{13}$ Batrus al-Bustāniy, Kitab Dā'irāt al-Ma'ārif(Beirut: Dār al-Ma'rifah, t.th.), 572.

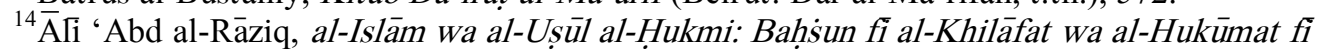
al-Islām (Mesir: Syirkah Sahiyat, 1925), 52.
} 
dengan nyawa atau dengan tenaga, pikiran, emosi, dan apa saja yang berkaitan dengan diri manusia. Sedangkan jihad adalah cara untuk mencapai tujuan. ${ }^{15}$ Rahmad Taufiq Hidayat mengatakan jihad ialah bersungguh-sungguh mencurahkan segenap pikiran, kekuatan dan kemampuan untuk mencapai suatu maksud atau untuk melawan suatu obyek yang tercela, seperti musuh yang kelihatan, setan atau hawa nafsu. Di samping itu juga, kata jihad mempunyai arti kekuatan perang atau bertempur melawan musuh. ${ }^{16}$

Ahmad al-Syarbaṣi mendefinisikan jihad secara umum artinya manusia mengerahkan segala daya dan kemampuannya dalam mewujudkan suatu tujuan. ${ }^{17}$ Menurut Hasan al-Banna, jihad adalah salah satu kewajiban muslim yang berkelanjutan hingga hari kiamat; tingkat terendahnya berupa penolakan hati atas keburukan atau kemungkaran dan yang tertinggi berupa perang di jalan Allah. Di antara keduanya adalah perjuangan dengan lisan, pena, dan tangan berupa pernyataan tentang kebenaran di hadapan penguasa yang zalim. Al-Ragib alAsfahāni menyatakan bahwa jihad adalah mencurahkan kemampuan dalam menahan musuh. Lebih lanjut al-Asfahāni menyatakan, jihad terbagi menjadi tiga macam, yakni berjuang menghadapi atau melawan musuh yang tampak, berjuang menghadapi setan, dan berjuang menghadapi hawa nafsu. ${ }^{18}$

Pendapat Kamil Salamah yang merujuk pada QS al-Ankabūt/29: 8, menyatakan bahwa jihad lebih luas cakupannya daripada aktivitas perang. Ia meliputi pengertian perang, membelanjakan harta, serta segala upaya dalam rangka mendukung agama Allah, berjuang melawan hawa nafsu, dan menghadapi setan. Hossein Nashr, terjemah jihad menjadi perang suci yang dikombinasikan dengan pemikiran Barat yang keliru tentang Islam sebagai agama pedang, mengurangi arti batini dan spiritualnya, serta mengubah konotasinya bahwa kehidupan pada hakikatnya mengimplikasikan gerak. Oleh karena itu, dalam menghadapi

\footnotetext{
${ }^{15}$ H. M. Quraish Shihab, Lentera Hati (Cet. II; Bandung: Mizan, 1994), 107.

${ }^{16}$ Rahmad Taufiq Hidayat, Khazanah Istilah Alquran (Cet. III; Bandung: Mizan, 1993), 71 73.

${ }^{17}$ Ahmad al-Syarbași, Yas'alūnaka fí al-Dīn wa al-Hayā', terj. Ahmad Subandi, Tanya Jawab tentang Agama dan Kehidupan (Cet. I; Jakarta: Lentera, 1997), 615.

${ }^{18}$ Muhammad Chirzin, Jihad Menurut Sayyid Qutb dalam Tafsir Zilal (Cet. I; Solo: Era Intermedia, 2001), 60-64.
} 
ketergantungan dunia pada perubahan atau gejala waktu yang fana, dan pada silih bergantinya eksistensi duniawi, untuk tetap berada dalam keseimbangan diperlukan upaya yang berkesinambungan dengan melaksanakan jihad pada setiap tahap kehidupan. Pada setiap momen kehidupan manusia harus berusaha menunaikan jihad hati menuju realitas ilahi, sumber kesadarannya. Melalui jihad hati, manusia spiritual mati dalam kehidupan dan mengakhiri semua mimpi, supaya bangkit menuju realitas yang merupakan sumber semua realitas. ${ }^{19}$

Menurut Azra, kata jihad secara literal berarti berjuang keras dan melukiskan usaha maksimal yang dilakukan seseorang untuk melawan sesuatu yang keliru. Kata jihad dalam Alquran sering diikuti frasa fî̀ sabīl Allāh. Orang-orang beriman diperintahkan berjuang dengan harta dan diri mereka karena Allah. Orang berjuang disebut mujāhid. Sebuah istilah lain yang berasal akar kata yang sama, yaitu ijtihad, mengacu pada upaya keras yang dilakukan oleh seorang sarjana untuk menetapkan satu hukum syari'ah. Oleh karenanya, seseorang yang memiliki kemampuan untuk menetapkan hukum suatu perkara secara mandiri disebut mujtahid. $^{20}$

Berdasarkan beberapa konsep jihad dalam perspektif tokoh dapat dipahami bahwa jihad pada prinsipnya adalah sebuah daya dan usaha yang dilakukan secara sungguh-sungguh, maksimal, berkesinambungan untuk mencapai sebuah tujuan yang dikehendaki.

\section{Memaknai Kembali Jihad di Era Milenial}

Kata jihad berasal dari akar kata jim, ha dan dal yang pada dasarnya mengandung arti "kesulitan dan yang memiliki kedekatan makna dengannya" (a1masyaqqah wa mā yuqārib bih). ${ }^{21}$ Kata jihad terambil dari kata jahd yang berarti letih atau sukar dan kemampuan. Jahd juga berarti kesulitan, puncak masalah, kesungguhan dan ujian berat (al-masyaqqah wa al-gayah wa al jadd wa al-imtiḥān).

\footnotetext{
${ }^{19}$ Ibid.

${ }^{20}$ Azyumardi Azra, Pergolakan Politik Islam: dari Fundamentalisme, Modernisme hingga Post Modernisme (Cet. I; Jakarta: Paramadina, 1996), 156-157.

${ }^{21}$ Abū Husain Aḥmad bin Fāris bin Zakariya, Mu’jam Maqāyis al-Lugah, Juz I, 486.
} 
Ia juga bisa terambil dari kata juhd yang berarti "kemampuan, kekuasaan dan pengorbanan" (al-tāqah wa al-wuṣ'a wa al-bażl). ${ }^{22}$ Tampak bahwa jihad merupakan kata yang bermakna luas. Secara leksikal jihad dapat diartikan sebagai upaya yang sulit, membutuhkan pengorbanan dan pengerahan segenap kemampuan yang dimiliki untuk mencapai suatu tujuan.

Jihad sebagaimana dalam hadis adalah amal yang utama. Keutamaan tersebut tergambarkan pada jaminan yang Allah berikan bagi para mujahid. Bahkan dalam hadis lainnya, urutan keutamaan jihad ditempatkan setelah salat tepat waktu dan berbakti kepada kedua orang tua. Maksudnya bahwa, seseorang yang telah beriman lalu ia berjihad di jalan Allah maka ia mendapatkan keutamaan berupa kedudukan yang mulia di sisi-Nya. Khusus pada kaum perempuan, maka jihad mereka adalah haji yang mabrur. Dalam redaksi yang lain, jihad juga dapat dilakukan dengan cara menyantuni janda dan fakir miskin, serta dengan cara berkata benar di hadapan penguasa. Hal ini dapat dilihat pada hadis berikut ini:

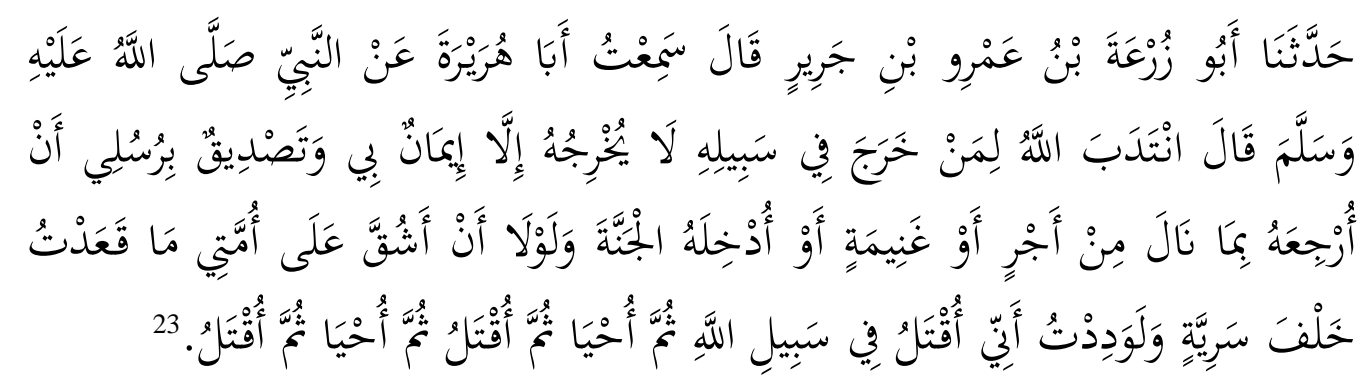

Artinya:

Abū Zur'ah berkata: Aku mendengar Abū Hurairah dari Nabi saw., beliau bersabda: "Allah menjamin orang yang keluar (berperang) di jalan-Nya, tidak ada yang mendorongnya keluar kecuali karena iman kepada-Ku dan membenarkan para rasul-Ku untuk mengembalikannya dengan memperoleh pahala atau ganimah (harta rampasan perang) atau memasukkannya ke surga. Kalau seandainya tidak memberatkan umatku tentu aku tidak akan duduk tinggal diam di belakang sariyah (pasukan khusus) dan tentu aku ingin sekali bila aku terbunuh di jalan Allah lalu aku dihidupkan lagi kemudian terbunuh lagi lalu aku dihidupkan kembali kemudian terbunuh lagi (HR al-Bukhāri).

${ }^{22}$ Al-Rāgib al-Isfahānì, Mu'jam Mufradāt Alfäz al-Qur'ān, 99.

${ }^{23}$ Muhammad bin Ismā‘ il bin Ibrāhim bin al-Mugirah al-Bukhārī, Saḥịh Bukhārīi, Juz 1 (Cet. I; Beirut: Dār al-Kutub al-Ilmìyah, 1992 M/1412 H), 63, Kitab Imān, Bab al-Jihād min al-İmān, Hadis No. 35. 


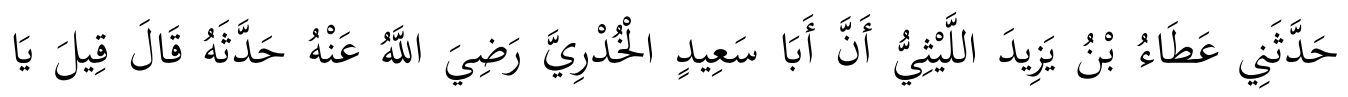

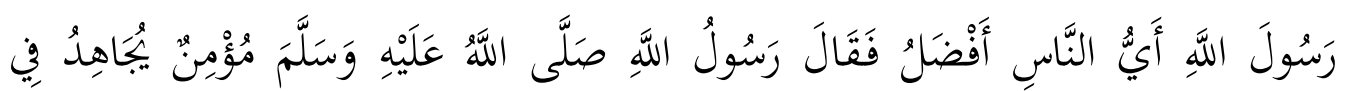

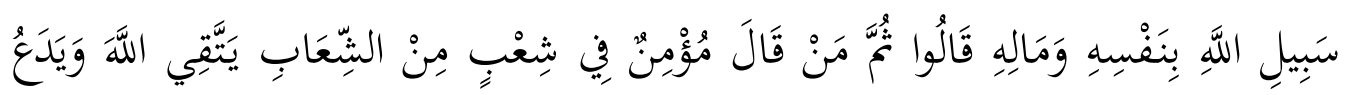
النَّاسَ مِنْ شَشِِّ.

Artinya:

'Ațā' bin Yazìd al-Laisìi berkata bahwa Abū Sa'ìd al-Khudri ra. bercerita kepadanya, katanya: "Ditanyakan kepada Rasulullah, siapakah manusia yang paling utama?" Maka Rasulullah saw. bersabda: "Seorang mukmin yang berjihad di jalan Allah dengan jiwa dan hartanya". Mereka bertanya lagi: "Kemudian siapa lagi?" Beliau menjawab: "Seorang mukmin yang tinggal di antara bukit dari suatu pegunungan dengan bertakwa kepada Allah dan meninggalkan manusia dari keburukannya (HR al-Bukhāri)

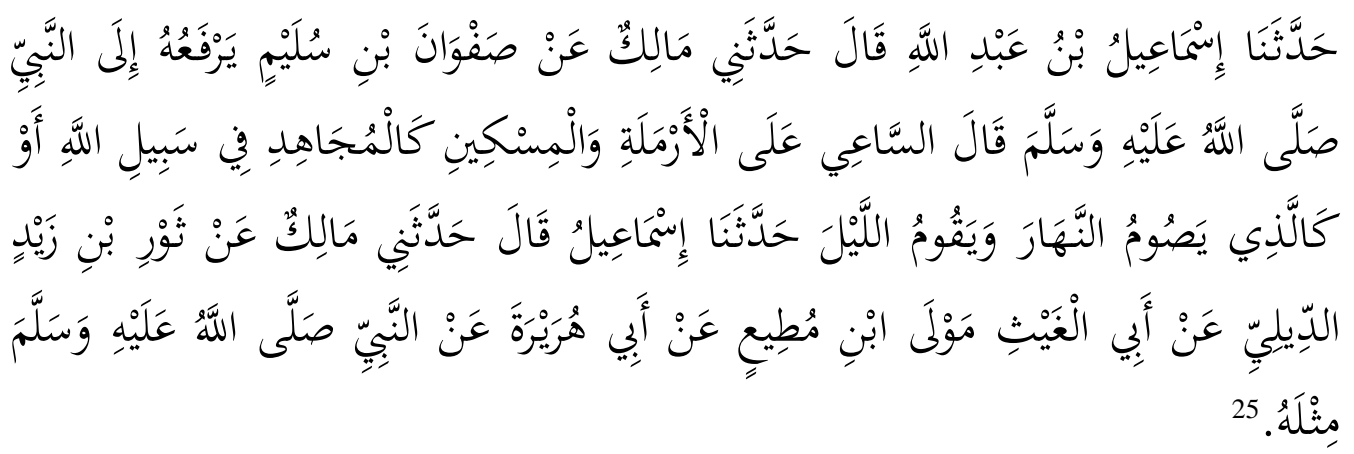

Artinya:

Isma'ìl bin 'Abdullāh berkata: telah menceritakan kepadaku Mālik dari Șafwān bin Sulaim yang (menyandarkannya) kepada Nabi saw. beliau bersabda: "Orang yang membantu para janda dan orang-orang miskin seperti orang yang berjihad di jalan Allah atau seperti orang yang selalu berpuasa siang harinya dan selalu salat malam pada malam harinya." Telah menceritakan kepada kami Isma'il dia berkata: Telah menceritakan kepadaku Mālik dari Sawr bin Zayd al-Dayli dari Abì al-Gays bekas budak Ibnu Muṭi ${ }^{\circ}$ dari Abi Hurairah dari Nabi saw. seperti hadis tersebut.

\footnotetext{
${ }^{24}$ Ibid., Juz 9, 349, Kitab al-Jihād wa al-Sï, Bab Af̣̣al al-Nās Mu'min Mujāhid bi Nafsih wa Mālih fỉ Sabìililāh, Hadis No. 2578.

${ }^{25}$ Ibid., Juz 18, 419.Kitab al-Adab, Bab al-Sà'ỉ alā al-Armalah, Hadis No. 5547.
} 
Kata أفضل yang disebutkan dalam hadis tentang jihad berbeda maknanya dengan kata الخير, Kata af̣̣lal memberi pengertian lebih utama dalam segi pahala, sedangkan kata khayr memberi pengertian lebih utama dalam masalah manfaat. ${ }^{26}$ Dengan demikian, pemahaman kontekstual hadis tentang keutamaan berjihad dapat dipahami sebagai motivasi bagi setiap muslim untuk berjihad agar mendapatkan pahala yang lebih banyak di sisi Allah swt.

Umat Islam dalam kehidupannya diharuskan untuk memperbanyak amal kebajikan, dengan demikian berjihad adalah suatu keharusan bagi mereka. Namun perlu diinterpretasi lebih lanjut bahwa jihad dalam artian mengangkat senjata melawan orang kafir adalah fardu kifayah, artinya bahwa jika sudah ada yang melaksanakannya, maka kewajiban berjihad menjadi gugur bagi orang lain. Jika tidak, maka siapa pun yang mengetahuinya berdosa, kecuali dalam tiga kondisi yang merupakan merupakan 'ain, yaitu:

a. Jika dua pihak sudah saling berhadapan, sehingga diharamkan untuk mundur dan berbalik.

b. Jika musuh menyerang suatu negeri dan mengepungnya, yang berarti mengharuskan semua orang untuk menghadapinya.

c. Jika imam (pemimpin Islam atau pemimpin perang) meminta umat Islam untuk berangkat berperang secara umum atau secara khusus ditujukan kepada orangorang tertentu. $^{27}$

Berkenaan dengan itu, maka jihad dalam arti perang sifatnya temporer, karena ada pengecualian bagi orang-orang tertentu untuk tidak ikut berperang. Demikian halnya, haji yang juga disebutkan dalam hadis di mana dalam kenyataannya, tidak semua umat Islam mampu melaksanakan ibadah haji tersebut karena adanya beberapa faktor, misalnya tidak memiliki dana yang cukup dan selainnya. Walaupun demikian antara jihad dan haji ganjarannya adalah pahala yang tinggi. 1994), 23

${ }^{26}$ H. M. Syuhudi Ismail, Hadis Nabi yang Tektual dan Kontekstual (Jakarta: Bulan Bintang, 2005), 1001.

"A Abdullah bin Āli Bassār, Taysīr Allām "terjemahan" (Cet. IV; Jakarta: Darul Falah, 
Pada kenyataannya tidak semua orang mampu ikut berjihad dalam arti perang, ajaran Islam yang universal masih memberi kesempatan bagi mereka yang tidak turut berperang untuk mendapatkan pahalah dengan cara berkata benar di hadapan pemimpin. Hal ini dapat ditemui dalam salah satu hadis selanjutnya, yakni; أَفْضَلُْ الْجِهَادِ كَلِمَةُ عَدْلٍ عِنْدَ سُلْطَانِ جَائرٍ . Dengan hadis ini, dipahami bahwa ada bentuk jihad lain selain perang. Bentuk jihad tersebut adalah berani menyampaikan sesuatu yang benar di hadapan pemimpin (penguasa).

Pada Kitab Awn Al-Ma'būd dijelaskan bahwa jihad adalah amalan yang paling besar pahalanya, karena banyak orang tidak mampu melakukannya. Jihad juga membutuhkan pengorbanan nyawa dan harta. Tanpa pengorbanan, tujuan jihad tidak akan tercapai. Ketika menghadapi pemimpin yang zalim dan dengan menyampaikan kepada sesuatu kebenaran biasanya seorang pemimpin merasa dibantah, dan akibatnya mengandung resiko tinggi. Jadi wajar bila seseorang yang berani menyatakan yang benar di hadapan pemimpin, sangat tinggi pahala yang diperolehnya. ${ }^{28}$

Pahala yang diberikan bagi orang berjihad, apakah ia berjihad dalam arti berperang melawan musuh-musuh Allah dengan nyawa dan hartanya, atau berjihad dalam arti mengungkap kebenaran di hadapan pemimpin, tiada lain adalah surga baginya. Perolehan surga ini oleh karena pahala jihad berlipat ganda, yakni pelakunya mendapat pahala lebih besar ketimbang dunia dan seisinya. ${ }^{29}$ Perlu menjadi catatan bahwa mengharap akan menjumpai musuh atau membanggabanggakan diri akan siap menanti kedatangan musuh adalah tindakan ujub yang memusnahkan pahala amalan. ${ }^{30}$

Hadis tentang jihad juga dijelaskan bahwa dunia hanyalah kehinaan jika dibandingkan dengan akhirat, dengan tujuan agar umat Islam berzuhud di dunia dan mengharapkan pahala di sisi Allah, sehingga mereka termotivasi untuk selalu berjihad. Juga dijelaskan bahwa pahala pergi pada petang atau pagi hari di jalan Allah

\footnotetext{
${ }^{28} \mathrm{Abū}$ al-Tāhif Muhammad Syamsi al-Nā'if al-Ażìm al-Abāđi, 'Awn al-Ma’būd, juz XX (t.t.: al-Maktabah al-Salafiyah, t.th), 449.

${ }^{29}$ Āì Bassār, Taysīir Allām,. 1008. 520.

${ }^{30}$ TM. Hasbi Ash-Shiddieqy, Mutiara Hadis, jilid V (Semarang: Pustaka Rizki Putra, 2003),
} 
meskipun hanya sekali saja, lebih baik dari pada dunia dan sisinya, karena seorang mujahid mendapatkan pahala yang besar dan melimpah sebab dia menjual dirinya yang berharga kepada Allah untuk mendapatkan pahala surga di akhirat kelak.

Memang setiap Muslim memiliki peluang untuk berjihad, namun bila dicermati hadis lainnya, mereka harus memilih sesuai dengan kondisi dirinya, apakah ia mau ikut berperang, atau berjihad dengan cara lain. Bentuk jihad selain perang ini tidak dibatasi oleh waktu (tidak temporal), karena kapan saja yang bersangkutan dapat bersedekah kepada para janda dan orang miskin, haji bagi mereka yang mampu, serta menyampaikan kebenaran di hadapan penguasa, dan kapan saja umat Islam boleh melalukan perang asalkan kaum kafir yang memulai.

Jika menelaah dari segi sejarah dikatakan bahwa pada awalnya, umat Islam dalam bulan-bulan tertentu tidak diizinkan untuk melakukan jihad dalam bentuk peperangan, terutama pada bulan Muharram apalagi saat dalam keadaan ihram. Tetapi dengan turun QS. al-Baqarah/2: 190-192, maka Allah mengizinkan berjihad dengan cara mengangkat senjata, yakni memerangi mereka (orang kafir Quraisy) demi membela agama Allah dan meninggikan kalimah-Nya. ${ }^{31}$ Adanya izin berjihad pada bulan Muharram, mengindikasikan bahwa jihad dalam arti memerangi orang kafir adalah suatu keharusan, namun hal itu dilakukan bilamana orang kafir melakukan penyerangan terhadap umat Islam.

Jika melihat term jihad ini dalam Alquran, maka ditemukan kata jihad dan kata yang seakar dengannya sejumlah 41 kali. $^{32}$ Dalam konteks perjuangan terdapat 28 ayat, 4 ayat turun pada periode Mekah dan 24 lainnya turun pada periode Madinah. Ayat-ayat jihad periode Makkiyah digunakan dalam konteks perjuangan dengan menggunakan al-Quran untuk mengajak kaum musyrik Quraisy mengikuti ajaran Islam dengan argumentasi logis (QS al-Furqān/25: 52). Selain makna perjuangan, ayat-ayat jihad periode Makkiyah juga berarti paksaan mempersekutukan Allah swt. (QS al-Ankabūt/29: 8 dan QS Luqmān/31: 15),

\footnotetext{
${ }^{31}$ Ahmad Musthafa al-Maraghi, Tafsir al-Marghi "terjemahan" (Cet. I; Semarang: Toha Putra, 1984), 165.

${ }^{32}$ Muhammad Fuad Abdul Baqi, Mutiara Hadist Shahih Bukhari Muslim (Jakarta: Bina Ilmu, 1979), 232-233.
} 
kesungguhan dalam bersumpah dan sabar dalam menghadapi cobaan. Tak satu pun yang berarti perjuangan dalam bentuk perang. Jihad dalam konteks Makkiyah adalah jihad dengan kesabaran, ketabahan menghadapi ujian fisik dan mental dari musyrik Quraisy dengan menggunakan argumentasi logis dan logika Alquran. Sedangkan ayat-ayat jihad periode Madinah memperkenalkan makna baru yaitu perjuangan secara konfrontatif dengan melakukan kontak fisik (perang). Ayat-ayat jihad periode ini turun seputar masa turunnya ayat tentang perintah berperang (qital). ${ }^{33}$

Menurut al-Rāgib al-Isfahāni, jihad dalam Alquran memiliki tiga arti: Pertama, berjuang melawan musuh yang nyata; Kedua, berjuang melawan setan; Ketiga, berjuang melawan nafsu. Sementara itu Ibnu Qayyim membagi musuh nyata dengan orang kafir dan munafik. Dari kedua ulama tersebut dan sesuai pengertian etimologinya maka jihad berarti menggunakan, mengeluarkan tenaga, daya upaya atau kekuatan untuk melawan suatu obyek yang tercela dalam rangka menegakkan agama Allah. Obyek itu adalah musuh yang nyata, setan dan nafsu. ${ }^{34}$

Perang merupakan arti khusus dari jihad yang mempunyai pengertian urnum. Menurut Muhammad Izzah Darwazah, pengertian khusus ini lebih banyak digunakan Alquran dari pengertian umumnya. Jihad khusus (perang) biasanya diikuti frase fì sabīlillāh dan bi amwālihim wa anfusihim. ${ }^{35} \mathrm{Hal}$ ini menunjukkan bahwa perang harus senantiasa berada dalam koridor sabìillāh. Secara umnm sabilillah dapat diartikan segala yang makruf dan mencegah yang munkar. Sedangkan penggunaan frase bi amwālihim wa anfusihim (dengan harta dan jiwa). Menunjukkan bahwa yang dituntut dalam perang adalah segala kesanggupan yang dimiliki, berupa harta, pengetahuan bahkan nyawa sekalipun. Sebagai bentuk perjuangan total demi tegaknya agama Allah. Hal ini menjadikan jihad sebagai spirit umat Islam yang luar biasa. Jika spirit ini dibawa ke medan perang maka akan muncul sebagai semangat pengorbanan hingga ke titik darah penghabisan.

\footnotetext{
${ }^{33}$ QS al-Baqārah/2: 218.

${ }^{34}$ Muhammad Fuad, Mutiara Hadist Shahih Bukhari Muslim, 232-233.

${ }^{35}$ Term jihad muncul sebanyak 16 kali bergandengan dengan frase ini baik secara lengkap maupun salah satunya saja. M. Fu'ad A. Baqi', Mutiara Hadist Shahih Bukhari Muslim, 232-233.
} 
Dengan demikian, jihad adalah kata yang bermakna luas yaitu perjuangan. Perjuangan yang menyeluruh dalam segala aspek kehidupan. Perjuangan melawan musuh yang nyata, pengaruh setan dan segala nafsu tercela. Sehingga sebagaimana arti etimologinya, jihad adalah puncak kepayahan setelah mengerahkan dan mengorbankan seluruh kemampuan.

Sebagaimana dijelaskan sebelumnya bahwa qital (perang) adalah bagian dari jihad. Qital adalah makna khusus dari jihad yang memiliki makna luas yakni perjuangan total yang meliputi seluruh aspek kehidupan untuk terwujudnya misi Islam yang sejati. Makna perang fisik atau mengangkat senjata terhadap para pembangkang Islam hanyalah salah satu manifestasi jihad yang diperintahkan. Jihad dalam bentuk ini menjadi sangat sentral di masa nabi, khususnya setelah hijrah ke Madinah.

Upaya untuk menghilangkan dan memberantas kejahatan adalah bagian dari makna jihad. Jihad terhadap kekufuran sebagai induk segala kejahatan mesti diupayakan secara terus menerus. Perintah jihad terhadap orang-orang kafir tentu saja dapat meliputi semua bentuk jihad seperti perang maupun perjuangan moral dan spiritual khususnya dalam upaya membendung pengaruh-pengaruh jahat mereka. $^{36}$

Namun ketika memerintahkan perang untuk pertama kalinya secara tegas Alquran menggunakan kata qital bukan dengan kata jihad, seperti qätilū (QS alBaqarah/2): 190, 193), uqtulü (QS a1-Baqarah/2: 191) atau menggunakan kata-kata harb (QS al-Baqarah/2: 279). Fakta ini dengan jelas membuktikan perlunya membedakan antara makna jihad dengan perang (qital, harb) atau setidaknya perlu memahami jihad secara lebih luas bukan sebatas perang fisik.

Jihad merupakan kata yang sangat sensitif karena adanya reduksi pemahaman atas maknanya. Jihad diidentikkan, bahkan kadang disamakan dengan perang. Pemahaman demikian tidak terlepas dari pengaruh penulis Eropa yang mengintroduksi jihad dengan istilah The Holy War (perang suci). Suatu terjemahan

\footnotetext{
${ }^{36}$ Harifuddin Cawidu, Konsep Kufr dalam al-Qur'an: Suatu Kajian Teologis dengan Pendekatan Tafsir Tematik(Jakarta: Bulan Bintang, 1991), 218.
} 
yang tidak dikenal dalam kepustakaan Islam sebelumnya. Melainkan diambil dari sejarah Eropa sendiri yang memahami istilah ini sebagai perang karena alasan keagamaan. Memang dalam Alquran dan hadis, jihad adalah perjuangan dengan motif dan tujuan keagamaan. Tetapi di dalamnya tidak terkandung pengertian "perang suci" sebagaimana dipahami dalam konteks sejarah Barat, apalagi identik dengan pengertian itu. ${ }^{37}$

Berbagai penafsiran mengungkapkan bahwa jihad adalah usaha yang sugguh-sungguh untuk mencapai sesuatu yang dilakukan dengan cara profesional yang didukung oleh modal yang mapan. Paradigma inilah yang digunakan untuk mendefinisikan makna jihad dalam konteks kekinian. Sementara itu, jihad dalam pengertian perjuangan moral dan spiritual, jihad tanpa kekerasan dan senjata telah dengan sangat jelas dikemukakan dalam beberapa ayat dan hadis. Perjuangan moral dan spiritual adalah perjuangan menegakkan keadilan, kebenaran, dan kesalehan sosial. Semua tema ini terangkum dalam istilah yang sangat populer dan menjadi inti keseluruhan perjuangan dalam kehidupan orang-orang beriman; "amar makruf nahi munkar".

Perintah Alquran dan hadis mengenai ini tidak dibatasi hanya terhadap lakilaki, tetapi juga perempuan. Meskipun pandangan-pandangan konservatif telah membatasi perjuangan kaum perempuan hanya dalam ruang sempit bernama keluarga, tetapi pandangan Tauhid, paradigma kesetaraan manusia dan keadilan, memberikan peluang kepada kaum perempuan untuk berjihad dalam ruang-ruang sosial, ekonomi, politik dan kebudayaan. ${ }^{38}$

Jihad membangun kebersamaan dan tanpa diskriminasi, menegakkan keadilan dan menghapuskan segala bentuk kezaliman, serta mewujudkan kesalehan sosial harus menjadi cara-cara kehidupan manusia ke depan. Inilah makna jihad sekaligus sebuah bentuk kerahmatan semesta yang menjadi cita-cita Islam. Jihad juga mengandung arti "kemampuan” yang menuntut sang mujahid mengeluarkan

\footnotetext{
Kunci, 511.

${ }^{37}$ M. Dawam Rahardjo, Ensiklopedi Al-Qur'an; Tafsir Sosial Berdasarkan Konsep-konsep

${ }^{38}$ H. M. Arifin, Psikologi dan Beberapa Aspek Kehidupan Rohaniah Manusia (Cet. II; Jakarta: Bulan Bintang, 1977), 77.
} 
segala daya dan kemampuannya demi mencapai tujuan. Karena itu jihad adalah pengorbanan, dan dengan demikian mujahid tidak menuntut atau mengambil tetapi memberi semua yang dimilikinya. Ketika memberi, dia tidak berhenti sebelum tujuannya tercapai atau yang dimilikinya habis. Jihad melawan segala macam bentuk penyelewengan yang bertentangan norma-norma agama dan kesepakatan sosial kemasyarakatan demi kemaslahatan umat dan penyerahan diri semata kepada Allah adalah bagian dari jihad dalam konteks kekinian.

Jihad adalah kekuatan yang memungkinkan Islam tetap eksis di bumi ini, dan inilah tujuan jihad, dan tidak ada jihad yang lebih utama dalam Islam kecuali jihad membela agama. Ulama-ulama menegaskan bahwa jihad membela agama selama musuh masih di luar wilayah negara, hukumnya farḍu kifāyah. Akan tetapi bila musuh telah memasuki wilayah hukumnya adalah farḍ 'ain, yakni wajib bagi setiap individu bangkit berjihad sesuai dengan batas kemampuan yang dimiliki masing-masing.

Begitupula, upaya memberantas kebodohan, kemiskinan, dan penyakit adalah jihad yang tak kurang pentingnya saat ini. Ilmuwan berjihad dengan memanfaatkan ilmunya, sementara jihad seorang karyawan adalah karyanya yang baik, guru dengan pendidikannya yang sempurna, pemimpin dengan keadilannya, pengusaha dengan kejujurannya, demikian seterusnya. ${ }^{39}$

Dahulu, ketika kemerdekaan belum diraih, jihad menimbulkan terenggutnya nyawa, hilangnya harta benda, dan terurainya kesedihan dan air mata. Kini harus membuahkan terpeliharanya jiwa, terwujudnya kemanusiaan yang adil dan beradab, melebarnya senyum dan terhapusnya air mata, serta berkembangnya harta benda. Inilah urgensi jihad yang harus dimaknai oleh setiap Muslim secara lebih luas sesuai dengan kemampuan dan posisinya, tidak memaksakan suatu makna jihad di luar kapasitasnya serta menyempitkan arti jihad dengan menimbulkan kekerasan fisik dan senjata yang kebanyakan hanya memberikan kesengsaraan dan kesedihan bagi manusia lainnya.

\footnotetext{
${ }^{39}$ H. M. Quraish Shihab, Lentera Hati, 518.
} 
Jihad harus tercermin dalam seluruh aktivitas kehidupan manusia. Jihad menghadapi rasa malas, serakah, kikir, curang, korup, iri dan dengki, dan sifat buruk lainnya. Jihad juga dalam dilakukan dengan harta benda (amwā̄). Dalam konteks ini, jihad yang dapat dilakukan antara lain dengan zakat, infak, dan sedekah, mengorbankan harta untuk membangun sarana pendidikan, sarana ekonomi, sarana kesehatan, dan lain-lain yang bertujuan untuk membangun kekuatan umat. Seiring dengan semakin berkembang dan majunya peradaban teknologi, jihad di era milenial juga dapat dilakukan melalui berbagai sarana media sosial, baik melalui WhatsApp, Instagram, Telegram, Facebook dan lain sebagainya dengan cara membangun narasi positif yang memberi motivasi kepada perbuatan baik dan peningkatan kesadaran beragama, melakukan counter wacana terhadap pendapat dan pandangan yang negatif, serta menjadi sarana membangun jaringan jamaah yang lebih kuat dan yang tidak lagi dibatasi oleh sekat-sekat wilayah (daerah).

Generasi-generasi muda Islam tidak boleh gagap teknologi, mereka harus menjadi benteng pelapis yang diharapkan dapat menjaga eksistensi Islam masa depan dengan kemampuan penguasaan teknologi dan jaringan, mampu menciptakan berbagai aplikasi yang memudahkan umat mengakses untuk belajar tentang Islam tanpa sekat mazhab sekaligus menyaingi kemampuan teknologi yang sengaja dibuat untuk melemahkan peradaban dan kejayaan Islam.

\section{Kesimpulan}

Hadis tentang keutamaan jihad menyimpulkan bahwa dengan janji dan jaminan yang disiapkan oleh Allah terhadap para mujahid, dipahami bahwasanya jihad merupakan bagian dari ibadah sosial umat Islam yang tidak dimiliki pada doktrin agama lainnya. Hadis ini juga dikuatkan oleh hadis lain yang mengungkapkan bahwa jihad adalah amalam utama setelah salat tepat waktu dan berbakti kepada orang tua. Hadis tentang jihad dengan nyawa dan harta menyimpulkan bahwa jihad membutuhkan pengorbanan yang besar, bahkan nyawa pun menjadi taruhannya. Jika yang dipertaruhkan adalah nyawa, maka jihad dalam 
hadis ini identik dengan perang fî̀ sabilillāh atau qitāl. Tanpa kesediaan untuk mengorbankan nyawa dan harta, niscaya tujuan jihad tidak akan tercapai. Pengorbanan tersebut juga diibaratkan seorang yang menjauhi kehidupan duniawi agar terhindar dari keburukan yang disebabkannya. Artinya, menjauhi keburukan duniawi juga merupakan jihad yang jaminannya sangat besar di sisi Allah swt. Hadis tentang jihad dengan menyantuni janda dan orang miskin menyimpulkan bahwa jihad dapat pula diwujudkan dengan cara menyantuni janda dan orang miskin. Keikhlasan untuk berbagai atas karunia yang Allah berikan membutuhkan perjuangan yang berat sebab tidak semua orang mampu berbagi atas nikmat yang dimilikinya. Bahkan, dalam redaksi yang berbeda pada hadis yang diriwayatkan oleh Bukhāri dan Muslim, menyantuni janda dan orang miskin diibaratkan seperti orang yang selalu berpuasa siang harinya dan selalu salat malam pada malam harinya. Tidak mudahnya salat dan puasa sepanjang hari semakin menegaskan betapa besarnya pahala menyant uni janda dan orang miskin.

Beragamnya bentuk-bentuk jihad yang diungkapkan oleh Nabi saw. dalam hadisnya berkonsekuensi terhadap pemaknaan kontekstualnya. Sebab, jihad bisa jadi mengalami distorsi makna oleh karena kesalahpahaman terhadap konteks hadis. Jihad dalam pengertian perang menjadi suatu yang wajib bagi umat Islam dalam kondisi perang dengan kewajiban mengorbankan nyawa dan harta, namun terdapat pengecualian bagi mereka yang berhalangan (uzur).

Pada kondisi yang lain, menyantuni janda dan orang miskin, menghindari keburukan dunia, berkata benar di hadapan penguasa, juga merupakan jihad yang tidak kalah besar pahalanya di sisi Allah swt. Perbedaan redaksi keutamaan jihad yang diungkapkan oleh Nabi saw. kemungkinan disebabkan pertimbangan situasional yang terjadi pada masa itu serta pertimbangan nabi terhadap kondisi psikologi seseorang yang menanyakan hal-hal yang utama dalam Islam. Oleh karena itu, penelusuran dengan melihat sebab turunnya (asbāb al-wurūd) hadis sangat diperlukan. 


\section{Daftar Pustaka}

'Abdul Hādi, Abū Maḥdi bin 'Abdul Qādir. Turuq Takhrīj Hadìs Rasūlillāh saw., dialihbahasakan oleh H.S. Agil Husin Munawwar dan H. Ahmad Rifqi Muchtar dengan judul Metode Takhrij Hadits. Cet. I; Semarang: Dina Utama, 1994.

Al-Abādì, Abū al-Tāhif Muhammad Syamsi al-Nā'if al-Ażìm. 'Awn al-Ma'būd, juz XX. t.t.: al-Maktabah al-Salafiyah, t.th.

Abd. al-Hayy al-Farmawi, Muqaddimah fī al-Tafsìr al-Qur'ān. Bairut: Dār al-'Ilmi, 1977.

Abdullah, Boedi. Taktis Jihad dalam Islam. Bandung; al-Ma'arif, 1978.

Ahmad, Arifuddin Paradigma Baru Memahami Hadis Nabi; Refleksi Pemikiran Pembaruan Prof. Dr. Muhammad Syuhudi Ismail. Cet. I; Jakarta: Renaisan, 2005.

Al-Hafiz, Ahsin A. W. Kamus Ilmu Al-Quran. Cet. I; Jakarta: Hamzah, 2005.

Al-Șālih, Subhi. Ulūm al-Hadiss wa Mustalāhuhu. Cet. XVII; Beirut: Dār al-'Ilm lil Malāyin, 1988.

Arifin, H. M. Psikologi dan Beberapa Aspek Kehidupan Rohaniah Manusia. Cet. II; Jakarta: Bulan Bintang, 1977.

Al-Asfahāniy, al-Ragib. Mu'jam Mufradāt Alfāz al-Qur'ān. Beirut: Dār al-Fikr, t.th.

Azra, Azyumardi. Pergolakan Politik Islam: dari Fundamentalisme, Modernisme hingga Post Modernisme. Cet. I; Jakarta: Paramadina, 1996.

Baqi, Muhammad Fuad Abdul. Mutiara Hadist Shahih Bukhari Muslim. Jakarta: Bina Ilmu, 1979.

Bassār, 'Abdullah bin Āli. Taysìr Allām "terjemahan". Cet. IV; Jakarta: Darul Falah, 2005.

Al-Bukhārì, Muhammad bin Ismā'il bin Ibrāhim bin al-Mugìrah. Saḥịh Bukhārì, Juz 1. Cet. I; Beirut: Dār al-Kutub al-Ilmìyah, 1992 M/1412 H.

Al-Bustāniy, Batrus. Kitab Dā'irāt al-Ma’ārif. Beirut: Dār al-Ma’rifah, t.th.

Cawidu, Harifuddin. Konsep Kufr dalam al-Qur'an: Suatu Kajian Teologis dengan Pendekatan Tafsir Tematik. Jakarta: Bulan Bintang, 1991. 
Chirzin, Muhammad. Jihad Menurut Sayyid Qutb dalam Tafsir Zilal. Cet. I; Solo: Era Intermedia, 2001.

Al-Dārimì, Abū Muhammad 'Abdillāh bin 'Abd al-Raḥmān. Sunan al-Dārimī, Juz 7. t.tp.: Dār al-Ihyā' al-Sunnah al-Nabawìyah, t.th.

Drake, Nicholas and Davis, Elizabeth (Eds.). The Concise Encyclopedia of Islam. Singapore: Tien Wah Press, 1989.

Fazlurrahman. Islam. New York: Achor Book, 1968. Major Themes of The Qur'an. Chicago: Bibliotheca Islamica, 1980.

Hanbal, Abū Abdullāh Ahmad. Musnad Ahamd ibn Hanbal, Juz 18. Beirut: Maktabah al-Islāmi, 1978.

Hidayat, Rahmad Taufiq. Khazanah Istilah Alquran. Cet. III; Bandung: Mizan, 1993.

Ismail, H. M. Syuhudi. Hadis Nabi yang Tektual dan Kontekstual. Jakarta: Bulan Bintang, 1994.

. Kaedah Kesahihan Sanad Hadis; Telaah Kritis dan Tinjauan dengan Pendekatan Ilmu Sejarah. Cet. II; Jakarta: Bulan Bintang, 1995. . Metodologi Penelitian Hadis. Cet. II; Jakarta: Bulan Bintang, 2007.

Keris (IT Developer), Lidwa Pusaka i-software, www.lidwapusaka.com.

Khallāf, Abd. Wahhab. 'Ilm Ușūl al-Fiqh. Cet. XII; Kuwait: Dār al-Qalam, 1978.

Al-Maraghi, Ahmad Musthafa. Tafsir al-Mă̈ghi "terjemahan" Cet. I; Semarang: Toha Putra, 1984.

Mālik, Imām. al-Muwațtā, Riwayat Yahya al-Laïsi. Beirut: Dār al-Fikr, t.th.

Manzūr, Ibnu. Lisān al-'Arb, Juz XV. Kairo: Dār al-Miṣriyah li al-Ta'Tif wa alTarjamah, t.th.

Munawwir, A.W. Kamus al Munawwir Arab-Indonesia. Cet. XXV; Surabaya: Pustaka Progresif, 2002.

Al-Naisabūīi, Muslim Ibn al-Hajjāj al-Qusyairī. Sahịḥ Muslim, Juz 9. Cet. I; Beirut: Dār al-Kutub al-Ilmìyah, 1994.

Al-Qazwaynī, Abū 'Abdillāh Muhammad bin Yazid. Sunan Ibn Mājah, Juz 8. Beirut: Dār al-Fikr, 1995. 
Rahardjo, M. Dawam. Ensiklopedi Al-Qur'an; Tafsir Sosial Berdasarkan Konsepkonsep Kunci. Cet. I; Jakarta: Paramadina, 1996.

Al-Rāziq, Āli 'Abd. al-Islām wa al-Ușūl al-Hukmi: Baḥsinn fî̀ al-Khilāfat wa alHukūmat fì al-Islām. Mesir: Syirkah Sahiyat, 1925.

RI, Departemen Agama. Al-Qur'an dan Terjemahnya. Jakarta: Dewan Penterjemah dan Pentahsis Al-Qur'an, 1998).

Ash-Shiddieqy, TM. Hasbi. Mutiara Hadis, jilid V. Semarang: Pustaka Rizki Putra, 2003.

Shihab, H. M. Quraish. Lentera Hati. Cet. II; Bandung: Mizan, 1994.

Al-Sijistānī, Abū Dāwud Sulaimān bin al-Asy'as Ibn Syaddād al-Azadì. Sunan $A b \bar{u}$ Dāwud, Juz 6. Beirut: Dār al-Fikr, 1968.

Al-Suyūṭi, Jalāl al-Dīn. Sunan al-Nasā $\bar{i}$, J Juz 10. Beirut: Dār al-Kutub al-Ilmìyah, t.th.

Surah, Abū Isāa Muhammad Ibn İsā Ibn. al-Jamī‘ al-Sahịḥ Sunan al-Turmużī, Juz 6. Beirut: Dār al-Kutub al-Ilmīyah, t.th.

Al-Syarbașī, Ahmad. Yas'alūnaka fī al-Dīn wa al-Hayā‘. Beirut: Dār al-Jail, t.th) diterjemahkan oleh Ahmad Subandi dengan judul "Tanya Jawab tentang Agama dan Kehidupan”. Cet. I; Jakarta: Lentera, 1997.

Wensinck, Arnold John. Concordance et Indices de la Musulmane, diterjemahkan oleh Muhammad Fuad Abd al-Baqy dengan judul al-Mu'jam al-Mufahras $1 i$ Alfäz al-Hadis al-Nabawi, Juz I. Leiden: EJ. Brill, 1936.

Zakarīya, Abū Husain Aḥmad bin Fāris. Mu’jam Maqāyis al-Lugah, Juz I. Beirut: Dār al-Fikr, 1979. 